\title{
PENGEMBANGAN MEDIA PROMOSI KESEHATAN TENTANG KESELAMATAN BERKENDARA SEPEDA MOTOR PADA SISWA SMA
}

\author{
DEVELOPMENT OF HEALTH PROMOTION MEDIA ABOUT SAFETY OF \\ MOTORCYCLE SAFETY TO SENIOR HIGH SCHOOL STUDENT
}

\author{
Tino Oktario Yosendha, Sri Widati \\ Departemen Promosi Kesehatan dan Ilmu Perilaku, \\ Fakultas Kesehatan Masyarakat, Universitas Airlangga, Surabaya \\ E-mail: tinonfs@gmail.com
}

\begin{abstract}
The Safety riding by motorcycle is important, especially for student in senior high school. The save of ride is needed because many student of senior high school use motorcycle to school. There are many cases of motorcycle accidents involve by student in senior high school, because the psychology of those who are still unstable and unwary. These research aims to make safety drive health promotion that's fits in SMA Budi Sejati Surabaya. This research using cross sectional research design. The first draft give pre test using questionnaire, than created some prototype and conducted testing of prototype used sampling students. This sample of population are 40 students and can be through by 32 students. Based on the result showed most responden are woman. The average 16-18 years. Most of the respondents have a good knowledge, attitude, motivation, and action. In addition the most responden have vulnerability feels to motorcycle accident. The media health promotion used poster about the importance of having drivers licence while driving by motorcycle and social media facebook.
\end{abstract}

Keywords: safety riding, driving licence, Senior High School

\begin{abstract}
Abstrak: Keselamatan berkendara sepeda motor sangat penting khususnya di kalangan siswa SMA. Keselamatan berkendara dibutuhkan karena saat ini siswa usia SMA banyak yang membawa sepeda motor ke sekolah. Banyak kasus kecelakaan sepeda motor yang melibatkan siswa usia SMA, karena psikologi mereka yang masih labil dan kurang waspada dalam berkendara sepeda motor. Penelitian ini bertujuan untuk membuat media keselamatan berkendara yang sesuai di SMA Budi Sejati Surabaya. Penelitian ini merupakan penelitian deskriptif dengan menggunakan rancangan penelitian cross sectional. Rancangan penelitian ini pertama dengan memberikan pre test menggunakan kuesioner, selanjutnya dibuat sebuah media, dan dilakukan uji media. Sampel dalam penelitian ini adalah keseluruhan populasi dari SMA Budi Sejati Surabaya yaitu 40 siswa dan yang dapat di teliti oleh responden adalah 32 siswa. Berdasarkan hasil data penelitian ini menunjukkan sebagian besar responden berjenis kelamin perempuan. Rata-rata berusia 16-18 tahun. Sebagian besar responden memiliki pengetahuan, sikap, motivasi dan tindakan yang baik tentang keselamatan berkendara sepeda motor. Selain itu sebagian besar responden merasa rentan terhadap kecelakaan sepeda motor. Media yang digunakan adalah poster tentang pentingnya memiliki SIM saat berkendara sepeda motor dan media sosial facebook.
\end{abstract}

Kata kunci: Keselamatan berkendara, SIM, Siswa SMA

\section{PENDAHULUAN}

Kecelakaan lalu lintas merupakan salah satu masalah kesehatan di dunia terutama di Negara berkembang. Kasus kecelakaan lalu lintas diperkirakan akan naik menjadi urutan ke - 3 di tahun 2020 (Natulya, 2002), Peningkatan kasus kecelakaan lalu lintas di Indonesia terjadi dari tahun ke tahun dimulai dari tahun 2010 berjumlah 66.488 hingga 2012 berjumlah 177.949 kasus (BPS, 2014), Jumlah kecelakaan lalu lintas di Indonesia didominasi oleh pengguna sepeda motor karena merupakan salah satu model transportasi yang banyak digunakan oleh orang dan harga yang terjangkau dapat memicu naiknya pengguna sepeda motor di jalan raya. Sepeda motor diminati oleh masyarakat karena dapat memberikan efisiensi biaya untuk perjalanan, dan unggul bermanuver di antara kemacetan di jalan. Kemudahan untuk mendapatkan sepeda motor menjadi penyebab naiknya tren menggunakan sepeda motor pada remaja khususnya usia sekolah. 
Berdasarkan wilayah Surabaya dibagi menjadi 5 bagian yaitu Surabaya, pusat, timur, barat, utara, dan selatan. Jumlah kasus kecelakaan terbanyak adalah pada Surabaya selatan dengan persentase $44 \%$ (Ditlantas Polda Jatim, 2014), Surabaya selatan dapat dibagi menjadi beberapa kecamatan yaitu kecamatan Wonokromo, kecamatan Wonocolo, kecamatan Wonocolo, kecamatan Wiyung, kecamatan Karang Pilang, kecamatan Jambangan, kecamatan Gayungan, kecamatan Dukuh Pakis, kecamatan Sawahan.

Jumlah kecelakaan lalu lintas pada 5 kecamatan tertinggi di Surabaya menunjukkan kecamatan Wonokromo menempati urutan kecelakaan tertinggi di wilayah Surabaya. Selanjutnya di tempati oleh kecamatan Mulyorejo, Gubeng, Karang Pilang, dan Krembangan pada tahun 2014. Kecamatan Wonokromo memiliki persentase kecelakaan terbesar sebanyak 20.5\% selanjutnya disusul dengan kecamatan Mulyorejo 7.1\%, kecamatan Gubeng 6.2\%, kecamatan Karang Pilang 5.4\%, kecamatan Krembangan 5.2\%, Kelompok usia 16-25 tahun menempati urutan tertinggi penyebab kecelakaan lalu lintas di Surabaya. Kecelakaan lalu lintas pada kelompok tersebut berjumlah 292 pada tahun 2013 dan 220 pada tahun 2014 (Polrestabes Surabaya, 2015),

Fenomena kecelakaan yang di dominasi oleh remaja yaitu remaja mempunyai emosi yang labil ketika di jalan. Ketidakstabilan emosi yang dimiliki oleh anak usia remaja dapat menimbulkan keinginan yang meledak-ledak.

Menurut undang-undang no 22 tahun 2009 batas usia minimal yang diperbolehkan mengendarai sepeda motor adalah 17 tahun. Pada usia 17 tahun seorang dapat mengajukan untuk pembuatan SIM. Jika ingin mendapatkan SIM seorang harus melalui tes yang telah disediakan untuk syarat kelulusan memperoleh SIM. Kepemilikan SIM merupakan syarat utama untuk mengendarai sepeda motor di jalan. Menurut undang-undang lalu lintas no. 22 tahun 2009 Pasal 1 no 23 menyebutkan bahwa pengemudi adalah orang yang mengemudikan kendaraan bermotor di jalan yang telah memiliki surat izin mengemudi.
Perilaku pelanggaran di jalan yang sering dilakukan oleh remaja yaitu menerobos marka jalan, mengabaikan lampu sein saat berbelok, tidak menggunakan helm saat berkendara, berkendara dengan kecepatan yang tinggi, kurang waspada saat berbelok dan menyeberang, tidak mempunyai SIM sudah berani menggunakan sepeda motor.

Faktor penyebab kecelakaan lalu lintas salah satunya adalah prasarana yaitu jalan raya. Perlu mendapat perhatian pemerintah untuk dapat menekan kecelakaan lalu lintas. Pemerintah dapat secara langsung mengatasi masalah kecelakaan lalu lintas yang berhubungan dengan sarana. Peran pemerintah terhadap kecelakaan lalu lintas hanya terbatas pada aturan dan sarana yang dipakai. Terkait karakteristik individu dapat dilakukan dengan memberikan edukasi dan kebijakan. Keselamatan berkendara lebih menekankan kepada wewenang masing-masing untuk menjaga dirinya dari kecelakaan lalu lintas.

Kesadaran individu dapat dimulai dari pengetahuan tentang keselamatan berkendara. Pengetahuan keselamatan berkendara sangat penting karena banyak siswa di SMA yang kurang mengerti arti rambu-rambu lalu lintas dan peraturan Undang-Undang yang mengatur tentang lalu lintas. Selain itu pengetahuan dapat memengaruhi persepsi, sikap dan motivasi siswa untuk melakukan suatu tindakan. Persepsi datang dari dalam diri ketika siswa merasa rentan terhadap terjadinya kecelakaan berkendara. Kerentanan yang dialami dapat menimbulkan sikap positif untuk lebih berhati-hati dalam berkendara di jalan raya. Sikap positif yang di tunjukkan tidak langsung membentuk tindakan melainkan perlu adanya stimulus untuk membentuk suatu tindakan. Stimulus karena berdasarkan pengalaman atau kognitif siswa. Kognitif yang baik akan membentuk tindakan yang sesuai dengan tujuan yang benar.

Agar media efektif dilakukan tahapan sesuai teori P-Proses. Tahapan P-Proses banyak digunakan untuk stakeholder yang ingin membuat media yang tepat sasaran. Sebagaimana peneliti hal ini untuk menentukan media yang sesuai 
dengan keinginan siswa SMA Budi Sejati Surabaya.

Tahapan pertama adalah menganalisis karakteristik, karakteristik yang didapatkan dianalisis untuk mengetahui dan menentukan faktor-faktor yang menyebabkan kecelakaan lalu lintas mulai dari umur, jenis kelamin, dan status sosial. Setelah karakteristik didapatkan selanjutnya adalah tahapan kedua pada P-Proses.

Tahapan kedua yaitu membentuk media komunikasi. Untuk membentuk media komunikasi langkah pertama yang dilakukan adalah menentukan khalayak sasaran. Setelah itu menentukan tujuan yang spesifik. Tujuan berkaitan dengan hasil yang akan diperoleh. Selanjutnya adalah menentukan isi, isi harus disesuaikan dengan keinginan responden. Isi tidak boleh berlebihan untuk mengurangi ketidakefektifan media yang telah dibuat. Isi dapat diperoleh melalui kuesioner dan wawancara kepada responden yang bersangkutan.

Tahapan ketiga adalah pengembangan media. Langkan yang dilakukan adalah membuat media sesuai keinginan responden. Hasil media yang dibuat harus berdasarkan dengan keinginan responden.

Setelah desain media di buat selanjutnya adalah uji coba media kepada beberapa responden. Uji coba dapat dilakukan dengan wawancara langsung oleh peneliti. Selanjutnya adalah dilakukan revisi media yang telah di uji coba kepada beberapa siswa tersebut.

Penelitian untuk menganalisis media yang sesuai dengan SMA Budi Sejati Surabaya perlu adanya suatu media yang sesuai terhadap pentingnya kepemilikan SIM pada saat berkendara di jalan raya.

\section{METODE}

Penelitian ini merupakan penelitian deskriptif dengan menggunakan pendekatan kuantitatif. Rancangan bangun pada penelitian ini adalah cross sectional.

Tahapan pertama yaitu memberikan pre test berupa kuesioner. Pre test dimaksudkan untuk melihat karakteristik responden yaitu umur dan jenis kelamin. Setelah itu dilakukan penyebaran kuesioner tentang pengetahuan, kerentanan, sikap, motivasi dan tindakan. Selanjutnya adalah merancang prototype untuk siswa berdasarkan P-Proses tahap ke dua. Prototype berupa poster yang dirancang dengan tema pentingnya kepemilikan SIM untuk berkendara di jalan raya. Setelah meluncurkan prototype dilakukan uji media terhadap lima siswa yang mewakili siswa di SMA Budi Sejati Surabaya dengan menggunakan personal review.

Populasi penelitian merupakan seluruh siswa di SMA Budi Sejati berjumlah 40 siswa sampel penelitian adalah keseluruhan populasi. Jumlah yang dapat diberikan kuesioner adalah 32 siswa. Karena beberapa siswa berhalangan untuk dimintai menjawab pertanyaan kuesioner.

Lokasi dan waktu penelitian terletak di SMA Budi Sejati Surabaya. Dengan waktu penelitian mulai bulan Januari hingga November 2016.

Data primer didapatkan langsung dari siswa melalui kuesioner, observasi lapangan dan wawancara. Data sekunder didapatkan dari TU dengan memberikan profil sekolah SMA Budi Sejati Surabaya.

Teknik pengumpulan data pre test menggunakan kuesioner dengan pertanyaan tertulis yang diisi langsung oleh responden. Observasi dilakukan dengan mengamati langsung berbagai fenomena yang ada di lingkungan sekolah untuk mengumpulkan data tentang perilaku siswa ketika jam istirahat, ruang kelas dan tempat parkir sekolah. Wawancara dilakukan tatap muka langsung dengan responden. Tatap muka dilakukan oleh lima orang siswa yang mewakili seluruh siswa di SMA Budi Sejati Surabaya.

Teknik analisis data menggunakan analisis deskriptif. Yaitu mendeskripsikan fenomena berdasarkan data yang terkumpul dengan menggunakan analisis deskriptif dengan mendeskripsikan pengetahuan, kerentanan, sikap, motivasi dan tindakan.

\section{HASIL PENELITIAN}

Informan dalam penelitian ini adalah siswa SMA Budi Sejati Surabaya. Jumlah seluruh siswa berjumlah 40 siswa. Namun yang dapat mengisi kuesioner media keselamatan berkendara berjumlah 32 siswa. 
Karena beberapa siswa pada saat dibagikan kuesioner sedang mengikuti kejuaraan mewakili sekolah. Umur responden paling banyak berusia 17 tahun dengan persentase sebesar $62,5 \%$.

Tabel 1. Karakteristik Responden Berdasarkan Umur dan Jenis Kelamin

\begin{tabular}{lcrr}
\hline \multicolumn{1}{c}{ Karakteristik } & F & \multicolumn{1}{c}{$\%$} \\
\hline Umur & 14 Tahun & 1 & $3,1 \%$ \\
& 15 Tahun & 4 & $12,5 \%$ \\
& 16 Tahun & 3 & $9,4 \%$ \\
& 17 Tahun & 20 & $62,5 \%$ \\
& 18 Tahun & 2 & $6,3 \%$ \\
& 19 Tahun & 1 & $3,1 \%$ \\
Jumlah & 20 Tahun & 1 & $3,1 \%$ \\
\hline Jenis Kelamin & Laki - Laki & $\mathbf{3 2}$ & $\mathbf{1 0 0 \%}$ \\
\hline Jumlah & Perempuan & 18 & $43,8 \%$ \\
\hline
\end{tabular}

Tabel 2. Pengukuran Pengetahuan, Kerentanan, Sikap, Motivasi dan Tindakan

\begin{tabular}{llc}
\hline \multicolumn{1}{c}{ Kelompok } & \multicolumn{1}{c}{ Kategori } & Presentase \\
\hline Pengetahuan & Kurang & $6,3 \%$ \\
& Cukup & $40,6 \%$ \\
& Baik & $53,1 \%$ \\
\hline Jumlah & & $\mathbf{1 0 0 \%}$ \\
\hline Kerentanan & Kurang Rentan & 0 \\
& Cukup Rentan & $9,4 \%$ \\
& Rentan & $90,6 \%$ \\
\hline Jumlah & & $\mathbf{1 0 0 \%}$ \\
\hline Sikap & Kurang & 0 \\
& Cukup & $6,3 \%$ \\
& Baik & $93,8 \%$ \\
\hline Jumlah & Kurang & $100 \%$ \\
\hline Motivasi & Cukup & 0 \\
& Baik & $3,1 \%$ \\
& & $96,9 \%$ \\
\hline Jumlah & Kurang & 0 \\
& Cukup & $37,5 \%$ \\
\hline Jumlakan & Baik & $62,5 \%$ \\
\hline
\end{tabular}

Usia tersebut merupakan usia remaja akhir. Ciri remaja akhir adalah masa puberitas yang ditunjukkan dengan bentuk tubuh dan cara berpikir. Jenis kelamin responden mayoritas berjenis kelamin perempuan dengan persentase sebesar $56,3 \%$, pada tabel 1 .

Hasil pengukuran sebesar 53,1\% pengetahuan siswa baik. Hasil yang diperoleh mendekati cukup karena beberapa siswa menjawab kuesioner dengan pertanyaan yang kurang tepat di jawab oleh responden pada pertanyaan peraturan mengenai kendaraan sepeda motor yang di atur di dalam undang-undang No. 22 Tahun 2009. Serta lambang jalan dengan lambang jalan memisah.

Hasil dari pengukuran kerentanan 90,6\% siswa merasa rentan terhadap kecelakaan berkendara. Mereka merasa khawatir ketika berkendara di jalan dengan tidak aman di jalan raya. Selain itu siswa merasa khawatir di jalan meskipun mereka menggunakan perlengkapan mengendarai sepeda motor yang lengkap. Ada perasaan yang membuat mereka merasa khawatir ketika ada pengendara yang kebut-kebutan di jalan.

Hasil dari pengukuran sikap 93,8\% siswa bersikap baik saat berkendara di jalan. Responden sebagian besar menjawab ingin mendapatkan SIM saat berkendara di jalan. Ini merupakan sikap positif dari dalam diri responden. Sikap positif yang di tunjukkan tidak menunjukkan tindakan yang positif oleh remaja. Menurut observasi banyak siswa yang tidak mempunyai SIM saat berkendara di jalan. SIM merupakan syarat wajib yang harus dimiliki oleh pengendara.

Hasil dari pengukuran menunjukkan 96,9\% siswa memiliki motivasi yang baik. Para siswa mempunyai keinginan untuk selamat ketika berkendara sepeda motor, Tetapi berdasarkan hasil dari kuesioner beberapa siswa memilih untuk tidak setuju ketika mengendarai sepeda motor perlu membawa SIM. Selain itu responden memilih menggunakan sepeda motor karena ingin terlihat keren oleh teman-temannya.

Hasil dari pengukuran $62,5 \%$ tindakan siswa baik. Hasil dari kuesioner responden tidak memiliki dan membawa SIM ketika mengendarai sepeda motornya ke sekolah. Ketika membuat SIM beberapa responden tidak membuat berdasarkan usia yang ditetapkan oleh undang-undang No. 22 Tahun 2009 yaitu ketika berusia 17 tahun sudah diperbolehkan membuat SIM. Beberapa siswa membuat SIM ketika 
berusia di bawah 17 tahun. Banyak siswa juga mengabaikan untuk membawa SIM saat berkendara sepeda motor. Meskipun jarak sekolah yang tidak terlalu jauh beberapa siswa menggunakan sepeda motor dan tidak membawa SIM nya ketika menggunakan sepeda motor.

Ketika diadakan observasi terlihat beberapa sepeda motor yang telah dimodifikasi oleh beberapa siswa. Beberapa siswa memilih menggunakan motor modifikasi ke sekolah agar terlihat lebih keren daripada siswa lainnya. Terlihat juga bahwa ada beberapa siswa yang menggunakan sepeda motor tidak menggunakan helm standar. Selain itu juga tampak halaman sekolah dipenuhi oleh sepeda motor siswa.

Hasil pengukuran media berdasarkan teori P-Proses terdiri dari beberapa tahapan. Tahapan pertama adalah mengidentifikasi karakteristik siswa. Didapatkan rata-rata siswa perempuan dengan usia 17 tahun. Tahapan kedua adalah desain media. Tahapan ini yaitu menentukan sasaran serta tujuan yang spesifik dan menentukan isi pesan dari media yang akan dibuat. Selanjutnya adalah mengembangkan media. Pengembangan media setelah membuat prototype selanjutnya adalah menguji coba media yang dibuat. Setelah mendapatkan hasil uji coba akan dilakukan revisi terhadap prototype yang dibuat.

Tabel 3. Pilihan Media

\begin{tabular}{lcc}
\hline Jenis Media & Media & Persentase \\
\hline Media visual & Poster & $40.6 \%$ \\
& Brosur & $37.5 \%$ \\
& Stiker & $21.9 \%$ \\
\hline Jumlah & & $\mathbf{1 0 0 \%}$ \\
\hline Media Sosial & Facebook & $46.9 \%$ \\
& Twitter & $12.5 \%$ \\
& Instagram & $40.6 \%$ \\
\hline Jumlah & & $\mathbf{1 0 0 \%}$ \\
\hline
\end{tabular}

Prototype yang banyak digemari oleh responden adalah media visual yaitu poster dengan persentase sebesar $40.6 \%$, Selain itu media sosial yang paling digemari responden adalah media facebook. Media facebook banyak digunakan oleh siswa seumuran mereka untuk sekedar mencari informasi atau sekedar mencari informasi dan berteman dengan teman yang mereka kenal di facebook.

Sebagian besar siswa di SMA Budi Sejati Surabaya adalah wanita maka artis favorit yang dipilih oleh responden yaitu Afgan dengan persentase sebesar $65,6 \%$,

Pilihan warna yang banyak di pilih responden adalah warna biru dengan persentase sebesar 53,1\%, Warna biru merupakan warna yang banyak disukai oleh kaum hawa karena memiliki nuansa yang cerah dan enak untuk dipandang. Menurut hasil observasi sarana di dalam kelas tidak terdapat LCD dan proyektor. Hanya ada beberapa poster yang di tempatkan di mading yang terdapat pada ruang tengah sekolah di antara ruangan kepala sekolah dan ruang TU SMA. Ruangan guru terdapat meja, kursi dan papan tulis serta beberapa almari dan komputer.

Indepth interview dengan salah seorang guru di sekolah bahwa kegiatan di sekolah menunjukkan belum adanya rutinitas mengadakan sosialisasi tentang keselamatan berkendara di sekolah. Serta tidak ada bantuan lembaga terkait untuk membantu kegiatan sosialisasi tentang keselamatan berkendara di sekolah

Berdasarkan hasil wawancara dengan humas sekolah tentang sosialisasi kecelakaan lalu lintas sebagai berikut:

"sudah pernah dilakukan mas, tetapi sudah lama dan itu pun ndak rutin di sini mas, soalnya di sini siswa nya sedikit, sosialisasi nya terakhir tahun 2015 sekarang belum ada sosialisasi lagi mas" (RN, 27 Juli 2016),

Berdasarkan hasil observasi kegiatan responden Kegiatan responden banyak digunakan untuk belajar di dalam kelas dan jika istirahat siswa banyak menggunakan waktunya di luar kelas. Kegiatan saat jam istirahat adalah bermain di halaman belakang sekolah bermain dengan teman sebaya atau ke kantin sekolah untuk menikmati makanan.

Tahapan selanjutnya adalah desain media. Media yang dibuat berdasarkan pilihan media berdasarkan teori P-Proses. Berikut ini adalah media yang dibuat:

Hasil dari rancangan media yang telah dibuat selanjutnya melakukan tahapan uji 


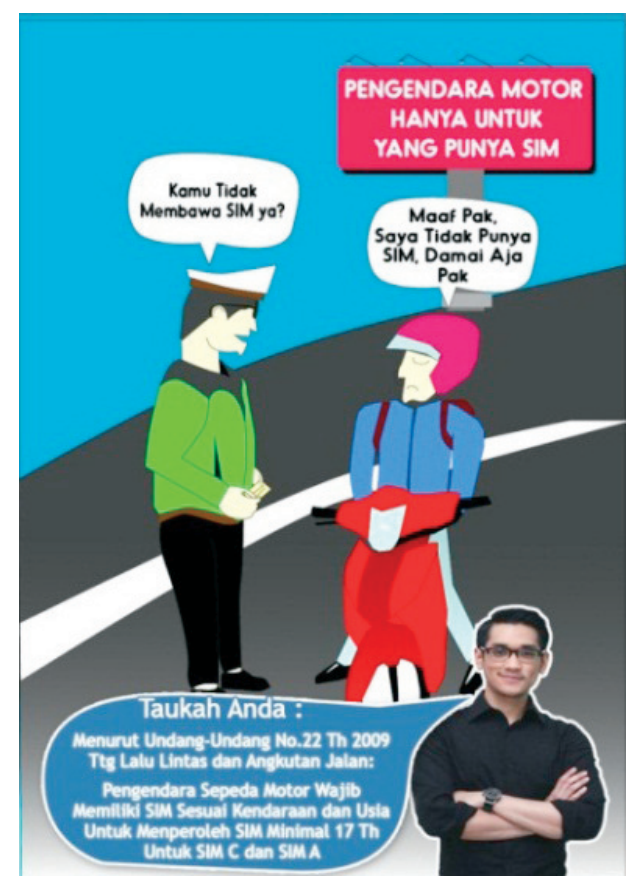

Gambar 1. Media Poster Tentang Keselamatan Berkendara

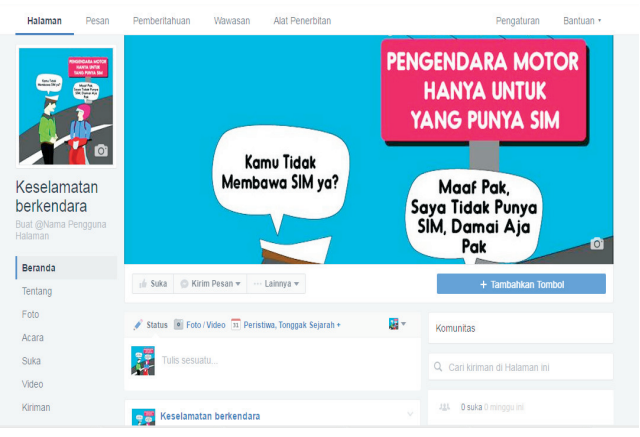

Gambar 2. Media Facebook Tentang Keselamatan Berkendara

coba dengan personal review kepada lima responden yang sebelumnya telah diberikan kuesioner.

Gambar poster diperlihatkan dan sebagian besar apa yang disampaikan di dalam poster responden mengerti, hasil jawaban oleh responden sebagai berikut:

"ngerti., poster ini njelasin orang yang nggak punyak SIM, intinya mengendarai motor harus punya SIM." (S,16 tahun),

"mengerti... bagi yang tidak punya sim bagi yang tidak punya sim diharapkan wajib mengurus dan segera memiliki SIM." (D, 17 tahun), "mengerti masksudnya kayak ada operasi trus minta damai. Maksudnya kalau berkendara wajib punya SIM, dan di sini jelas ada undang-undang nya." (E, 7 tahun),

Gambar dan tulisan diperlihatkan memiliki daya persuasi dan mengajak responden untuk melakukan tindakan. Berikut jawaban responden:

"iya ...menyuruh untuk membuat SIM." (E, 17 tahun)

"iya...menyuruh melakukan sesuatu seperti di poster membuat dan memiliki SIM." (DP, 17 tahun),

Beberapa siswa kurang setuju terhadap kata ajakan untuk mengajak siswa untuk membuat SIM pada umur yang ditentukan dan membawa SIM ketika berkendara sepeda motor. Berikut merupakan jawaban responden :

"belum, karena tidak ada ajakan untuk melakukan sesuatu, ajakan dalam bentuk kata-kata." (D, 17 tahun),

Bahasa yang dipakai di dalam poster sebagian besar menjawab sudah baik dan dapat dimengerti dengan jelas. Berikut adalah jawaban dari responden:

"bahasanya dimengerti dengan jelas." (DP, 17 tahun),

"bahasanya sudah baik dan tidak menyinggung." (E, 17 tahun),

“sudah baik dan sopan." (I, 17 tahun),

Sebagian besar kata-kata di dalam poster sudah berhubungan dengan tujuan untuk memberikan edukasi kepada siswa terhadap pentingnya kepemilikan SIM. Berikut adalah hasil jawaban dari responden:

"sudah berhubungan kak." (D, 17 tahun),

Menurut pendapat siswa kata-kata yang ada di dalam poster mereka menyatakan setuju dan sudah jelas. Berikut adalah hasil jawaban responden:

"sudah baik dan sopan, kata-katanya tidak bertele-tele." (DP, 17 tahun),

"suka kata-kata dalam posternya." (E, 17 tahun), 
Menurut responden suka terhadap gambar yang di gunakan di dalam poster. Berikut adalah jawaban dari responden:

"suka gambarnya lucu karena gambarnya kartun.” (E, 17 tahun),

"suka dan sudah jelas." (D, 17 tahun),

"sudah bagus." (I, 17 tahun),

Menurut mereka poster yang telah dibuat tidak membuat mereka bingung. Berikut ini adalah jawaban responden:

"tidak... karena di dalam poster ada tulisan pengendara wajib memiliki sim pada usia 17 tahun dan wajib membuat sim ketika berkendara." (DP, 17 tahun),

"tidak ada yang membuat bingung." (S, 16 tahun),

Beberapa siswa menjawab tulisan dengan latar belakang kotak merah membuat mereka bingung. Berikut ini adalah hasil dari jawaban responden:

"saya bingung ada kotak merah di dalamnya ada tulisan pengendara motor hanya untuk yang punya sim itu, itu maksutnya ada cegatan motor trus di tulisin itu atau bagaimana?, " (D, 17 tahun),

Sebagian besar mengatakan bahwa poster tersebut lebih baik dipajang di dalam kelas. Berikut adalah jawaban responden:

"poster ini bagus di pajang di mading di kelas kak" (E, 17 tahun),

“di mading kelas kak." (S, 16 tahun),

Sebagian besar menjawab sebaiknya dipasang di kantin sekolah. Berikut ini adalah hasil jawaban responden:

"di kantin... karena semua siswa pasti menuju kantin dari kelas 1 sampai kelas 3." (DP, 17 tahun),

"di tembok parkiran sama di pohon di dekat parkiran." (D, 17 tahun),

"di parkiran... karena anak banyak ndak punya SIM." (I, 17 tahun),

Hasil dari personal review media facebook terhadap lima responden yang sebelumnya sudah diberikan kuesioner.
Responden dipilih dengan acak dan tidak ada intervensi apapun.

Gambar 2, fanpage facebook diperlihatkan kepada responden. Sebagian besar responden menjawab mengerti terhadap gambar di fanpage yang diberikan. Berikut ini adalah jawaban dari responden :

"ngerti kak. Ini gambar poster di taruh di fanpagenya", (S, 16 tahun)

Media facebook diperlihatkan memiliki daya persuasi untuk mengajak melakukan suatu tindakan. Berikut ini adalah hasil dari jawaban responden :

"menyuruh untuk membuat SIM." (E, 17 tahun),

Bahasa yang dipakai dalam media facebook sebagian besar menjawab sudah baik dan jelas. Berikut hasil dari jawaban responden :

"bahasanya mudah dimengerti, dan sudah baik." (DP, 17 tahun),

Hasil dari personal review media poster dan media facebook selanjutnya direvisi sesuai dengan hasil dari personal review yang dilakukan oleh lima responden. Hasil dari perbaikan berupa perbaikan gambar animasi dan perbaikan kata-kata. Ditambah dengan penghapusan gambar artis. Gambar artis memerlukan persetujuan dari artis, peneliti belum mempunyai persetujuan untuk menaruh gambar artis di poster tersebut.

Berikut ini adalah hasil dari revisi media yang dilakukan oleh peneliti:

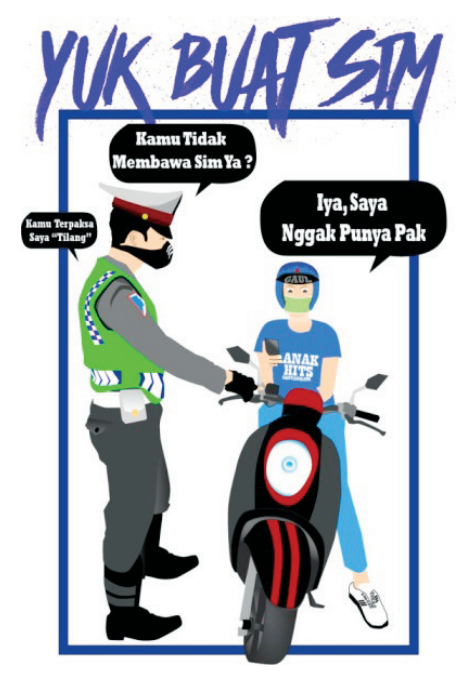

Gambar 3. Hasil Revisi Media Poster 
Poster yang telah di revisi yaitu menghilangkan kotak merah dan memberikan kata-kata ajakan. Selain itu mendesain gambar. Serta memperbaiki warna pada baju polisi warna motor dan warna baju pelanggar. Perbaikan selanjutnya adalah memperbaiki tulisan percakapan supaya lebih jelas dan mudah dibaca.

Media yang efektif menurut hasil identifikasi dari kuesioner, observasi, maupun indepth interview adalah media poster dan facebook. Pembuatan media visual dan media sosial disesuaikan dengan keinginan responden melalui kuesioner meliputi warna, gambar, konten pesan.

Pesan yang disampaikan berupa imbauan untuk pengendara khususnya adalah kendaraan sepeda motor yang digunakan oleh remaja awal atau remaja dengan rentang usia 14-17 tahun bahwa jika menggunakan sepeda motor harus terlebih dahulu memiliki SIM dan membuat SIM pada usia yang ditentukan undang-undang No. 22 tahun 2009 tentang lalu lintas dan angkutan jalan. Poster yang dibuat adalah berupa gambar animasi karena banyak disukai oleh responden.

Hasil dari revisi media poster adalah isi pesan yang diberikan kata ajakan, kata ajakan penting menurut siswa karena jika ingin mengajak sesuatu harus berupa kata ajakan. Selanjutnya adalah menghapus gambar artis Afgan dan menghapus tulisan undang-undang. Peneliti belum mempunyai ijin untuk memasang foto Afgan di poster utama menurut pertimbangan yang dilakukan adalah menghapus gambar tersebut. Tulisan undang-undang jika di pasang pada dinding akan terlihat kecil dan tidak mampu dibaca dengan baik oleh responden, maka tulisan di hapus oleh peneliti.

\section{PEMBAHASAN}

Menurut undang-undang lalu lintas dan angkutan jalan (2009) kecelakaan lalu lintas adalah peristiwa yang tidak diduga sehingga mengakibatkan korban atau kerugian. Sehingga diperlukan kesadaran pengemudi sepeda motor untuk patuh terhadap lalu lintas agar kejadian kecelakaan dapat di hindari.
Upaya merancang media menggunakan teori P-Proses agar media yang dibuat dapat diterapkan kepada siswa untuk lebih mengerti dan patuh terhadap peraturan lalu lintas. Khususnya siswa berusia 17 tahun karena pada usia tersebut adalah usia sesorang untuk berpikir yang matang sebelum melakukan tindakan.

Tahapan pertama merancang media berdasarkan P-Proses adalah mengidentifikasi karakteristik responden. Karakteristik responden banyak berusia 17 tahun dan berjenis kelamin perempuan. Usia 17 tahun adalah fase remaja akhir seorang. Usia tersebut dianggap seseorang mampu berpikir secara dewasa untuk sebelumnya melakukan tindakan tertentu. Anak usia remaja adalah fase dimana seorang anak melakukan suatu tindakan berdasarkan tingkat emosional dan keinginan mereka. Banyak peristiwa kecelakaan yang melibatkan anak usia sekolah karena banyak dari mereka yang belum siap untuk mengendarai sepeda motor tapi memaksakan untuk mengendarainya. Kecelakaan yang melibatkan remaja banyak dari mereka yang kurang menggunakan peralatan berkendara seperti tidak menggunakan Helm dan alat pelindung lainnya. Penelitian ini juga sejalan dengan penelitian Saputra (2014) tentang persepsi anak di bawah umur terhadap keselamatan berkendara sepeda motor di perumahan Manjul, bahwa anak yang berada di bawah umur mengindikasikan kurang pengetahuan yang cukup tentang perlengkapan berkendara sepeda motor.

Tahapan kedua adalah desain komunikasi. Pada tahapan ini adalah menentukan isi dari media yang akan di buat untuk menentukan media yang akan dibuat terlebih dahulu menganalisis pengetahuan, kerentanan, sikap, tindakan, motivasi dari siswa yang ada di SMA Budi Sejati Surabaya. Pengetahuan yang dimiliki tentang keselamatan berkendara sudah baik tetapi banyak dari siswa yang tidak mengerti tentang undang-undang lalu lintas. Ketika ditanya tentang undang-undang lalu lintas hampir sebagian besar menjawab tidak tahu. Selanjutnya adalah kepemilikan SIM banyak siswa yang menjawab SIM tidak wajib digunakan untuk berkendara. Menurut 
mereka SIM digunakan untuk razia biar tidak tertangkap polisi. Pentingnya SIM sebagai syarat utama dalam berkendara harusnya dimengerti dengan baik karena pentingnya memiliki SIM adalah kewajiban seseorang untuk berkendara. Menurut undang-undang lalu lintas dan angkutan jalan No. 22 Tahun 2009 untuk mendapatkan SIM calon pengemudi harus memiliki kompetensi mengemudi yang diperoleh melalui pendidikan atau pelatihan. Seseorang yang memiliki SIM adalah seseorang yang memiliki kompetensi untuk berkendara yang benar di jalan raya. Maka dari itu pentingnya untuk memiliki SIM harus ditanamkan sejak awal. Agar siswa tidak salah mengerti kegunaan dari SIM yang sesungguhnya. Selanjutnya adalah kerentanan berkendara. Siswa merasa rentan ketika berkendara di jalan. Mereka merasa rentan ketika berkendara tidak menggunakan peralatan yang lengkap seperti Helm dan kepemilikan SIM. Siswa yang tidak mempunyai SIM akan merasa khawatir ketika di jalan karena mereka menggunakan sepeda motor tetapi tidak memiliki SIM. Keadaan seperti ini banyak dialami oleh seluruh siswa yang ada di sekolah karena mereka merasa khawatir ketika di tilang di jalan karena tidak mempunyai SIM saat berkendara di jalan. Selanjutnya adalah sikap siswa terhadap keselamatan berkendara mayoritas siswa bersikap baik ketika berkendara. Selanjutnya adalah motivasi dan tindakan motivasi yang baik akan di teruskan menjadi tindakan yang baik. Sebagian besar siswa mempunyai motivasi dan tindakan yang baik namun, sebagian besar siswa tidak mengerti pentingnya memiliki SIM saat berkendara di jalan. Berdasarkan hasil faktor kepemilikan SIM di dominasi faktor internal siswa yaitu diri mereka sendiri. Faktor internal dipengaruhi oleh sikap individu dalam keselamatan berkendara. Hal ini sejalan dengan penelitian Yogatama (2013) bahwa faktor internal individu dipengaruhi oleh sikap seorang individu terhadap pengambilan keputusan.

Tahapan ketiga adalah merancang media. Rancangan media didapatkan hasil bahwa media poster dan media sosial facebook yang banyak digemari oleh siswa. Tahapan pembuatan media di buat dengan nuansa warna biru. Menurut Notoatmodjo (2012) warna mempunyai pengaruh terhadap perilaku seseorang yaitu bentuk reaksi dan tindakan. Selain itu dibuat gambar berupa animasi agar disukai oleh siswa. Rata-rata mereka menyukai poster bergambar animasi karena menurut mereka poster dengan gambar animasi lebih tertarik dibanding poster dengan banyak gambar dan tulisan. Tema dari poster adalah pentingnya memiliki SIM saat berkendara di jalan. Tema ini disesuaikan menurut tahapan teori P-Proses.

Tahapan selanjutnya adalah uji coba media yang dilakukan terhadap lima siswa yang sudah diberikan kuesioner. Tahapan ini untuk mengetahui bagaimana media tersebut agar dapat diterima dengan baik di lingkungan mereka. Setelah dilakukan uji coba media yang di buat dilakukan revisi sesuai keinginan siswa.

Berdasarkan teori Edgar Dale pembelajaran dibagi menjadi tujuh tahapan yang berbentuk kerucut. Tahapan melihat, memetik pelajaran sebanyak $30 \%$, Serta tahapan melihat dan mendengar, sebanyak 50\% Shimoff (2008), Menurut hasil rata-rata siswa menyukai media berbentuk gambar serta berbentuk gambar dan suara. Siswa menyukai media berbentuk gambar karena menurut mereka lebih terlihat menarik. Hal ini sejalan dengan penelitian Herlina (2015) berjudul penggunaan media belajar dalam upaya meningkatkan hasil pembelajaran di sekolah. Penelitian tersebut mengungkapkan penggunaan media overhead projector (OHP) jauh lebih baik dibandingkan dengan pembelajaran tanpa media pembelajaran.

\section{KESIMPULAN}

Pengembangan media untuk siswa SMA Budi Sejati Surabaya adalah media visual berupa poster dengan bertema wajib memiliki SIM saat berkendara di jalan. Selain itu media sosial berupa facebook media sosial digunakan untuk menyuarakan tulisan keselamatan berkendara agar siswa dapat dengan mudah memahami 
dan mengetahui keselamatan berkendara dengan baik dan benar khususnya tentang kepemilikan SIM.

\section{DAFTAR PUSTAKA}

Badan Pusat Statistik. 2014. Data Jumlah Kecelakaan, Luka Berat, Luka Ringan, dan Kerugian Materi.

Ditlantas Polda Jatim. 2014. Data Kecelakaan Lalu Lintas 2014.

Herlina, N. 2015 Penggunaan Media Belajar Dalam Upaya Meningkatkan Hasil Pembelajaran di Sekolah. Jurnal.

Nantulya, V.M., Reich R.R. 2002. The neglected epidemic : road traffic injuries in developing countries. BJM. 324: 113-41.

Notoatmodjo, S. 2005. Promosi Kesehatan Teori dan Aplikasinya. Jakarta: Rineka Cipta.

Notoatmodjo, S. 2007. Promosi Kesehatan dan Ilmu Perilaku. Jakarta: Rineka Cipta.

Notoatmodjo, S. 2012. Promosi Kesehatan dan Perilaku Kesehatan. Jakarta: Rineka Cipta.
Maulana, H. D. J. 2009. Promosi Kesehatan. Jakarta : Buku Kedokteran EGC.

Porlestabes Surabaya. 2015. Laporan Kecelakaan Lalu Lintas Kota Surabaya Tahun 2014.

Saputra, A. K., Djumaidi, Z. 2014. Presepsi Anak di Bawah Umur Terhadap Keselamatan Berkendara Sepeda Motor di Perumahan Munjul. Jurnal Kesehatan Masyarakat.

Shimoff, M., Kline, C. 2008. Happy For No Reason. (diterjemahkan oleh : Sofia Mansoor), Jakarta : PT Gramedia Pustaka Utama.

Undang-Undang No. 22 Tahun 2009 tentang Lalu Lintas dan Angkutan Jalan. Sekretariat Negara RI. Jakarta.

Yogatama, L. A. M. 2013. Analisis Pengaruh Attitude, Subjektive Norm, dan Preceived Behavior Control Terhadap Intensi Penggunaan Helm Saat Mengendarai Motor Pada Remaja dan Dewasa Muda di Jakarta Selatan. Jurnal Psikologi, Vol.5. 